\title{
The dentition of Carodnia vieirai (Mammalia: Xenungulata): enamel microstructure and mastication pattern
}

\author{
Lílian Paglarelli Bergqvist and Wighart von Koenigswald
}

\begin{abstract}
Post canine teeth of the Paleogene Carodnia from Brazil were investigated in regard to the enamel microstructure and the mastication pattern. The enamel is entirely prismatic, and the interprismatic matrix (IPM) is oriented parallel to the prisms, which consist of Boyde's patterns 1 and 2. The prominent vertical Hunter-Schreger-bands (HSB) are restricted to an outer zone, whereas the inner zone is formed by transverse but irregular HSB. Such a combination is very rare in mammalian teeth, but shows some similarities to the schmelzmuster of specific perissodactyls, where it evolved independently. Significant differences to Astrapotheria were found. The mastication pattern can be derived from the orientation of the wear facets on the transverse lophs. In stages of moderate tooth wear, the lophs have one-sided planar facets that are inclined in the upper and lower teeth antagonistically. Enamel crests on the leading sides cut like scissors. Subsequently, the antagonistic shear-cutting crests of the lophs pass each other and compress the food items until central occlusion. Thus, the jaw movement during phase I is predominantly mesial with a distinct inclination upwards. No traces indicate a phase II of the power stroke. Neither the enamel nor the widelydistributed mastication pattern offer convincing arguments to support any of proposed phylogenetic relationship of Carodnia. The rare schmelzmuster contributes to the diversity of enamel microstructures in South American ungulates.
\end{abstract}

Lílian Paglarelli Bergqvist. Departamento de Geologia, Universidade Federal do Rio de Janeiro, Av. Athos da Silveira Ramos 274, Prédio CCMN, 21941-611, Rio de Janeiro/RJ, Brasil. bergqvist@geologia.ufrj.br Wighart von Koenigswald. Universität Bonn, Steinmann-Institut (Paläontologie), Nussallee 8, D-53115 Bonn, Germany. koenigswald@uni-bonn.de

Keywords: Xenungulata; Itaboraí basin; schmelzmuster; mastication; vertical Hunter-Schreger bands (HSB); reflecting light method (RLM)

Submission: 20 July 2016 Acceptance: 2 June 2017

Bergqvist, Lílian Paglarelli and von Koenigswald, Wighart. 2017. The dentition of Carodnia vieirai (Mammalia: Xenungulata): enamel microstructure and mastication pattern. Palaeontologia Electronica 20.2.30A: 1-15 palaeo-electronica.org/content/2017/1898-enamel-microstructure-carodnia

Copyright: @ June 2017 Society of Vertebrate Paleontology. This is an open access article distributed under the terms of the Creative Commons Attribution License, which permits unrestricted use, distribution, and reproduction in any medium, provided the original author and source are credited.

creativecommons.org/licenses/by/4.0/ 


\section{INTRODUCTION}

The order Xenungulata Paula-Couto, 1952 is the most striking and enigmatic order of endemic South American Paleogene mammals that lived from early Paleocene to early Eocene (Simpson, 1935; Paula-Couto, 1952; Villarroel, 1987; Gelfo et al., 2008). It encompasses two families, three genera, and at least five formal species: (1) Carodniidae (Paula-Couto, 1952), with Carodnia feruglioi Simpson, 1935 (Patagonia, Argentina; early Paleocene sensu Woodburne et al., 2014a), Carodnia vieirai Paula-Couto, 1952 (Rio de Janeiro, Brazil; early Eocene) and Carodnia inexpectans Antoine, Billet, Salas-Gismondi, Lara, Baby, Brusset, Espurt, 2015 (Quebrada Cabeza de Vaca, Peru; early Eocene) (2) Etayoidae (Villarroel, 1987), with Etayoa bacatensis Villarroel, 1987 (Bogotá, Colombia; middle Paleocene?) and Notoetayoa gargantuai Gelfo, López, and Bond, 2008 (Patagonia; early - late Paleocene sensu Woodburne et al., 2014). A possible new species, from Rio Loro Formation (Northwestern Argentina), remains undescribed and unnamed (Bergqvist and Powell, 2004).

An almost complete unassociated skeleton of Carodnia vieirai was recovered in Itaboraí, a city located approximately $60 \mathrm{~km} E$ of the city of Rio de Janeiro, Brazil (Paula-Couto, 1952), making $C$. vieirai the best-known xenungulate species. Two complete mandibles (DGM 333M and 334M), with distinct size and morphology of the ramus (Bergqvist et al., 2008a, b), are evidence that at least two individuals were preserved associated in Itaboraí basin (Bergqvist et al., 2006).

Carodnia vieirai is peculiar among South American ungulates for bearing bilophodont first and second molars (Paula-Couto, 1952). Although $\mathrm{m} 1$ is unknown for the other Carodnia species, it is reasonable to believe that it was bilophodont too, suggesting it is a common feature of the genus. The two transverse ridges converge inwardly in M3, meeting at the tip of the protocone in a Vshape. The talonid of $\mathrm{m} 3$ is fully developed, and the bilophodonty is not as pronounced as in m1-2 (Figure 1). Its large body size and forelimbs more robust and longer than its hindlimbs (Bergqvist et al., 2006) also separates $C$. vieirai from other contemporary South American mammals.

Carodnia vieirai is the largest xenungulatan and also the largest South American early Eocene mammal. Its body mass, estimated both by postcranial (Avilla and Bergqvist, 2005; Bergqvist and Metello, 2011) and dental measurements (Metello and Bergqvist, 2012; Antoine et al., 2014), was
$550-650 \mathrm{~kg}$, and its body size was $2 \mathrm{~m}$ long. According to Avilla and Bergqvist (2003, 2005), C. vieirai would have been a slow cursorial mammal with homolateral locomotion, but Abranches (2012) suggested a semiaquatic habit. The microwear analysis of $C$. vieirai suggested that its diet was intermediate between browsers and grazers, but composed of an abrasive diet, possibly closer to C3 grazers or folivorous browsers (Abranches, 2012).

Enamel is a highly-mineralized tissue that forms the outermost layer of reptilian and mammalian tooth crowns. In mammals, the enamel is organized into bundles of hydroxyapatite crystallites, called enamel prisms, which vary in morphology, diameter, and packaging (Loch et al., 2015). Enamel types are defined by the orientation and arrangement of the prisms. Several enamel types may contribute to the enamel of individual teeth. The 3D arrangement of different enamel types within a tooth is defined as schmelzmuster (Koenigswald, 1980). The microstructure of mammalian tooth enamel has been investigated for a long time, but greater attention was devoted to this topic with the development and greater availability of scanning electron microscopes (SEM) in the 1980s (Koenigswald and Clemens, 1992). Two main factors influence enamel structure: phylogenetic heritage and functional adaptations (Koenigswald and Pascual, 1990). The relationship between stresses and complex structures reflects functional constraints, but phylogeny is also implicated in enamel differentiation and variability, as some specific enamel structures have close correlation with specific mammalian taxa (Koenigswald, 1997a). Thus, the study of tooth enamel microstructure can provide several characters useful for phylogenetic analyses, allowing better understanding of the evolution of different enamel types and their spatial combination in the schmelzmuster (e.g., Koenigswald and Rose, 2005).

It was during the early Paleocene that radial enamel, in which prisms follow a straight course from the enamel-dentine junction to the outer tooth surface, gave rise to the more complex enamel type, the Hunter-Schreger bands (HSB) (Koenigswald et al., 1987). The HSB are layers of decussating prisms. The "configuration of HSB" (Koenigswald et al., 2011) is important because they may be oriented more or less transverse or vertical in relation to the growing axis of the tooth.

In the teeth of early Paleocene mammals horizontal HSB occurred only in the central zone of the enamel and had a low angle of decussation, while 


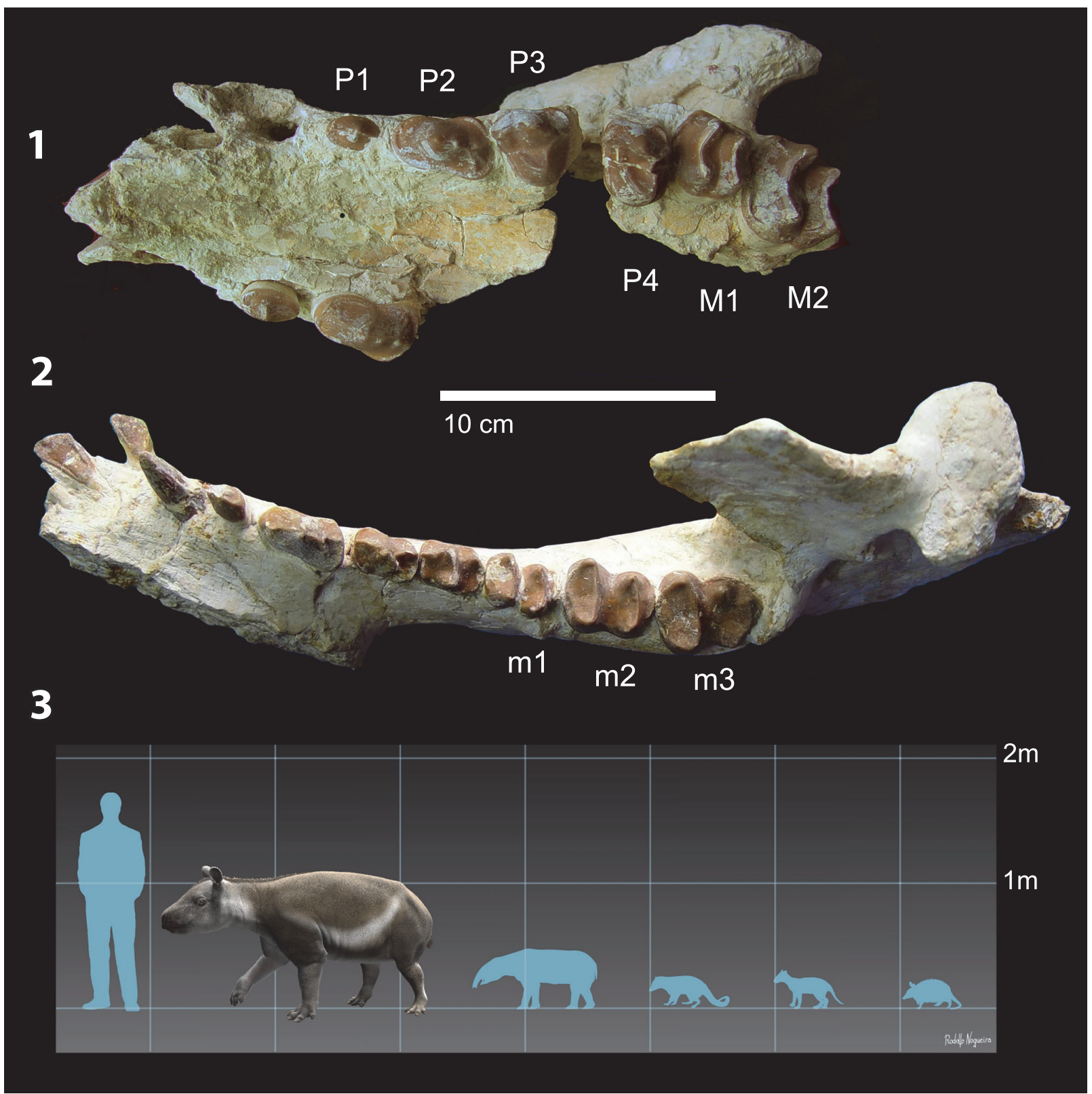

FIGURE 1. Carodnia vieirai. (1.1) Fragmented skull (DGM 335M) and (1.2) right mandibular ramus (DGM 334M); (1.3) life reconstruction and its comparative size to other Itaboraí species (from left to right: Tetragonostylops apthomasi (Astrapotheria), Patene simpsoni (Metatheria), Colbertia magellanica (Notoungulata), Riostegotherium yanei (Xenarthra); art by Rodolfo Nogueira.

in late Paleocene forms it extended throughout the enamel and the decussation angles reached nearly $90^{\circ}$ (Koenigswald et al., 1987). Vertical HSB are known from various perissodactyls but as well in some rodent incisors (Rensberger and Koenigswald, 1980; Kalthoff, 2000; Koenigswald et al., 2011). The configuration of vertical HSB was also described for Carodnia (Line and Bergqvist, 2005).

It is assumed that the formation of HSB generally improves the physical and mechanical proper- ties of enamel, especially by avoiding the propagation of cracks and, perhaps by increasing wear resistance (Pfretzschner, 1994; Rensberger, 2000; Line and Bergqvist, 2005). But details of the functional advantage, e.g., why the HSB are oriented differently in the inner and the outer zone, are still open. The fact that specific enamel structures characterize specific mammalian groups indicates that the enamel structure is always a 
combination of the functional and phylogenetic signal.

At the same year, Lindenau (2005) presented a detailed survey of the microstructure of several South American ungulates while Line and Bergqvist (2005) described the microstructure of Itaboraí basin ungulates. They investigated the enamel microstructure of Carodnia vieirai under reflecting light microscopy and described HSB at the external surface of the enamel as vertical with many bifurcations. The present study aims to provide a detailed description of the complex microstructure of $C$. vieirai using a combination of the "Reflecting Light Method" (RLM sensu Koenigswald and Rose, 2005; Koenigswald et al., 2015) and scanning electron microscopy.

\section{MATERIALS AND METHODS}

All specimens of Carodnia vieirai were recovered from one of the fissure-fill deposits that cut the fresh water travertine that fills the Itaboraí basin, in the state of Rio de Janeiro, southeastern Brazil (Paula-Couto, 1952). Since Marshall (1985), Itaboraí basin has been referred to Itaboraian SALMA (58.3-57 Ma sensu Bond et al., 1995). Recent analyses of Paleogene mammalian assemblages and mammal-bearing deposits in Argentina, together with new radioisotopic dating (Gelfo et al., 2009; Woodburne et al., 2014a, b), suggested that Itaboraian SALMA in Argentina is somewhat younger than previously believed, probably ranging from 53 - $50 \mathrm{Ma}$ (early Eocene).

Some of the arguments raised by Gelfo et al. (2009) and Woodburne et al. (2014a) in regard to an early Eocene age of the Itaboraí basin, however, are controversial. For instance, the authors employed the age of the siliceous hydrothermal cementation (sensu Sant'Anna and Riccomini, 2001), a post-diagenetic event that occurred locally in the basin, as the age of the limestone deposition. The siliceous cementation is directly associated with the ankaramite dike and cannot be used to support a lower age for the basin. Moreover, the fauna of Itaboraí basin has always been considered, and compared to other South American faunas, as a single unit, but the composition of the paleomastofauna of each fissure suggests that they were not filled synchronically. While a more comprehensive study and comparison are not undertaken to reevaluate the real age of Itaboraí basin, we will follow the proposed rising of Itaboraian age to early Eocene.

The holotype (DGM 333M) and paratype (DGM 334M) specimens are housed at the fossil mammal collection of Museu de Ciências da Terra, Rio de Janeiro, Brazil. As mentioned above, the holotype and paratype mandibles are distinct in size and morphology of the ramus, but both mandibles remain assigned to $C$. vieirai, as no differences were found among the teeth of both specimens, or among the postcranial bones recovered associated with the mandibles. Hunter-Schreger bands, however, are best visible in teeth of the paratype.

About 40 teeth of Carodnia vieirai were reviewed under reflected light microscope. Due to the destructive nature of the microstructure analyses and the scarcity of isolated and/or uncatalogued specimens, samples used in this study comprise one molar fragment (KOE 4121, KOE 4122), one undetermined fragment (KOE 4133 assigned to $C$. vieirai due to the thickness of its enamel and the pattern of the HSB that is distinct from other Itaboraí species with vertical HSB [see Line and Bergqvist, 2005) and a complete left p1 (UFRJ-DG 315M) of Carodnia vieirai. The three specimens were recovered from the same fissure fill deposits of the holotype and paratypes. Several sections in different orientations were prepared in all specimens.

Two methods of observation were employed here: the traditional scanning electron microscopy (SEM) method and the reflecting light method (RLM). For both analyses, dental samples were imbedded in epoxy resin. After setting for about 12 hours, Carodnia tooth fragments and left $\mathrm{p} 1$ tooth were sectioned in three planes using a low speed saw: transverse, radial, and tangential (Koenigswald, 1997b). Grinding was done on moistened SiC grinding paper ( $P$ 600) and then on a glass plate with grinding powder (P 1000). Samples were subsequently etched with $10 \%$ hydrochloric acid for three seconds. After ultrasonic cleaning, specimens were sputter-coated with gold and examined using two different scanning electron microscopes (SEM): a Camscan MV 2300 SEM housed in the Steinmann Institut (Universität Bonn, Germany) and a JEOL JSM-6460LV, housed at Laboratório de Microscopia Eletrônica of Instituto Alberto Luiz Coimbra de Pós-Graduação e Pesquisa de Engenharia of UFRJ, Brazil. Magnifications in the instrument ranged from $400 \mathrm{X}$ to $6000 \mathrm{X}$.

The reflecting light method (RLM) provides important structural details at relatively low magnification using a binocular microscope (Koenigswald and Rose, 2005 and Koenigswald et al., 2014; Figure 2.1-3). The effect of the RLM was discovered by chance, as it was an unintended side effect that 

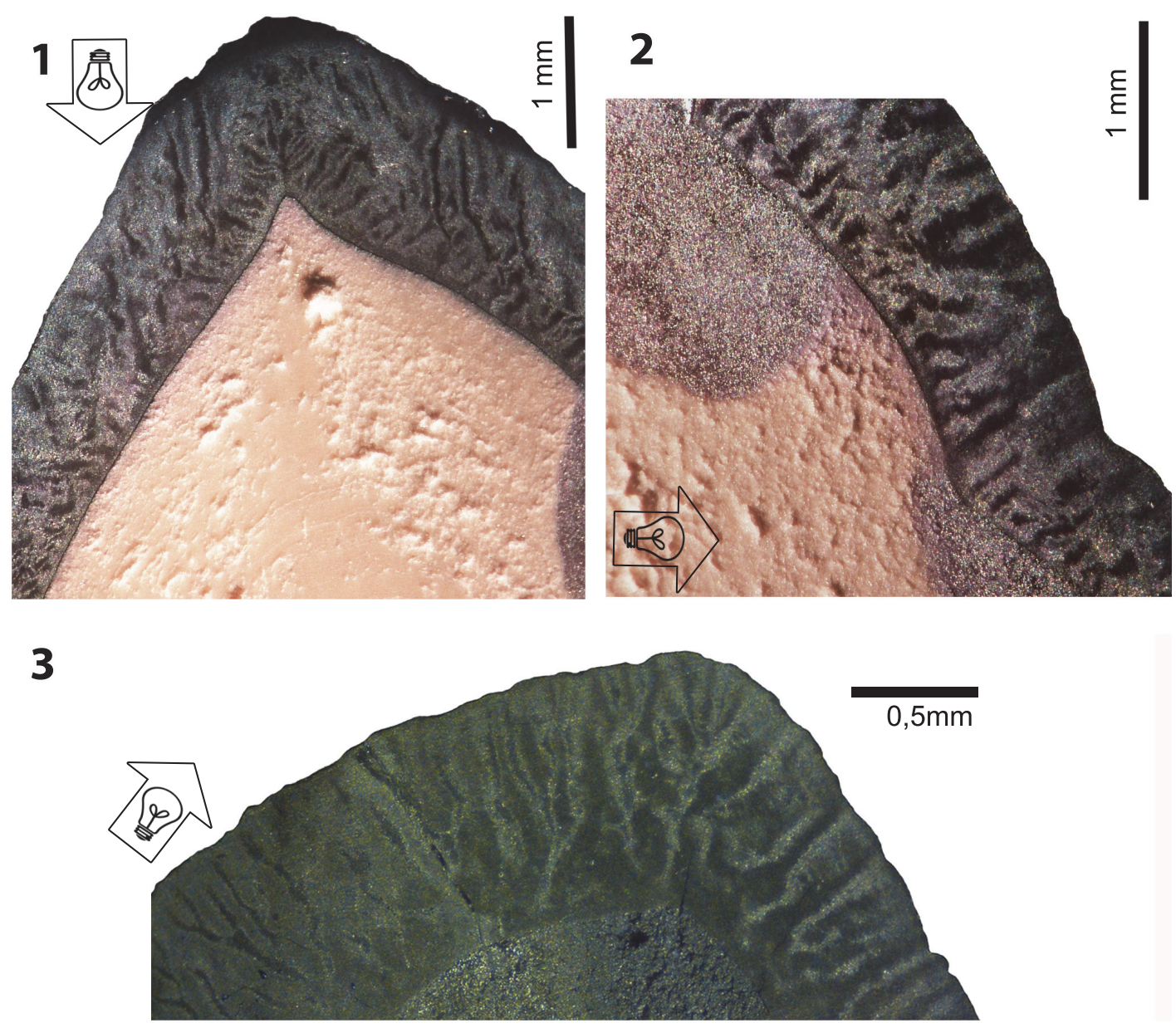

FIGURE 2. Carodnia vieirai (UFRJ-DG 315M), vertical (2.1-2) and transverse (2.3) sections of a left p1 in reflected light images (RLM). The grounded, etched and sputter coated sections were illuminated almost tangentially from different sides, indicated by the arrows framing the lamps. Areas of similar prisms orientation reflect in the light in the same intensity. The vertical section (2.1) is passing through the tip, whereas (2.2) shows the labial side, about the midpoint. All sections show the difference between the inner and the outer zone. The location of the light bulb in each photography shows where the illumination come from.

happened during the preparation of enamel sections for SEM analysis. It can be applied to etched ground sections prior to or after sputtering. This method allows for survey of larger areas of identical prism orientation, and even very small groups of prisms with different orientation show up. Thus, structures that are repeating in larger areas can be made visible. A light guide effect of the enamel prisms causes differences in color on the polished (and etched) enamel surfaces. In sputtered specimen, it is the reflection of the light according to the topography of etched surfaces that illuminates field of similar prisms orientation. The reflection of light is dependent on the angle between prism direction and light source, therefore a movable focused light source is required. Thus, the appearance of the surface changes when the light source is moved from one side to the other (light bands turn dark and vice-versa), as different sets of prisms are illuminated depending on the orientation of the light source. Pictures obtained using RLM were taken using both a stereomicroscope Zeiss Axio Zoom.V16, at Steinmann Institut, and a Zeiss Stereo Discovery V12 at Laboratório de Geologia Sedimentar of Instituto de Geociências (UFRJ). Magnifications ranged from $15 x$ to $40 x$.

The terminology used here followed the glossary proposed by Koenigswald and Sander (1997).

\section{Institutional Abbreviations}

DGM - Divisão de Geologia e Mineralogia of Museu de Ciências da Terra, Rio de Janeiro, Bra- 
zil; KOE - lab number of enamel collection in the Steinmann Institut für Geologie Mineralogie und Paläontologie der Universität Bonn, Germany; UFRJ-DG - Universidade Federal do Rio de Janeiro, Departamento de Geologia.

\section{RESULTS}

\section{The Enamel Microstructure of Carodnia}

This is not the first investigation of the enamel of Carodnia, but no detailed descriptions have previously been presented. Line and Bergqvist (2005) undertook the first examination of the enamel of microstructure of Carodnia, but only from the outside of the teeth, and observed the presence of vertical but much bifurcated HSB. The new analysis of all available teeth of Carodnia here undertaken, indicated that vertical HSB, with its typical bifurcations, are present in all tooth positions and on all sides of the teeth, and that the bifurcation is more intense at the tip of the cusps.

A first glimpse of the internal microstructure of Carodnia can be taken from the observation of the outer enamel surface of the teeth. They are ornamented with a pattern of interconnected ridges and valleys, more visible and marked in successional teeth than in molars, which present the same orientation and bifurcation of the HSB (when observed from the outside with RLM).

Crystallites, prisms and IPM. The enamel microstructure is best described following the various levels of its complexity (Koenigswald and Clemens, 1992). The entire enamel of Carodnia vieirai is fully prismatic, with prisms running from the enameldentine junction (EDJ) to the outer enamel surface (OES) (Figure 3.1-5). The average enamel thickness is $1.5 \mathrm{~mm}$, ranging from 1.1 to $1.6 \mathrm{~mm}$. In general, there is no outer layer of prismless enamel, only insignificant patches of prismless enamel were detected.

The crystallites of the interprismatic matrix (IPM) consists of apatite crystallites like in the prisms, oriented parallel to the prisms and well separated from crystallites of the prisms by the prism sheath (Figure 3.2-4). The preservation of the IPM is dependent on the fossilization and etching during preparation. The fact that individual crystallites are visible, suggests that no (or minimal) diagenetic alteration affected the enamel microstructure. The crystallites are visible at 2000x magnification as very fine crystals less than $0.3 \mu \mathrm{m}$ in diameter (Figure 3.2). The length of these needles could not be estimated from our images, but according to Daculsi et al. (1984), they are at least 200x longer than thick.

The prisms in Carodnia are rounded in crosssection and are surrounded by a prism sheath (Figure 3.1-2). According to a tangential section near the EDJ, the prism sheath is thicker and mostly closed, whereas in another tangential section, near the OES, the sheath is thinner and the prisms are opened to one side more frequently (Figure 3.1). In the SEM photos, the prism-sheath appears as a dark and narrow trench edged more deeply. The IPM is visible between the prism sheaths. It forms a shell around the bending prisms and becomes visible in sections that are almost parallel to the prisms causing the uppermost prisms to fall out (Figure 3.5). It indicates that the prism sheath separates prisms from the IPM even in some depth.

Because the prisms are not straight but curved, their appearance in cross-section varies strongly with the angle of the section. Thus, the prism may occur rounded or as a high oval, and the open side of the sheath may be hidden. Under a specific angle, the prisms sometimes look like the keyhole pattern (Figure 3.3), but the ends of the open prism-sheaths do not meet, as they do often in the keyhole pattern. In some areas, the prisms are arranged more or less in horizontal rows due to their dense packing, while in others, the IPM is thicker and the prisms are distributed more randomly. The cross-sections of the prisms were measured near the EDJ $(4.5 \mu \mathrm{m}, \min 3.3$, max 5.6, $\mathrm{n}=20)$ and close to the EDJ $(4.7 \mu \mathrm{m}, \min 3.2$, max 5.7, $n=30$ ), and no major difference was found. Some sections invoke the idea that the IPM may be thicker near the EDJ and thinner close to the OES but this could not be confirmed by measurements.

Despite the observed variations, the prisms of Carodnia can be characterized as rounded with an open or closed prism sheath and surrounding IPM in their entire length. This prism type, widely distributed among mammals, was classified as prism types 1 and 2 according to Boyde (1965).

The schmelzmuster. Regarding the schmelzmuster, the first question is whether the enamel is one layered or composed out of different enamel types. The answer is obvious if different enamel types are involved, but the available sections of Carodnia vieirai show a somewhat complicated pattern.

According to the pictures provided from sections in the RLM (Figures 2.1-3 and 4.1-2) or in the SEM (Figure 5), three zones can be recognized. The thickness and the boundaries of these two major zones vary and thus the term zones is used, 

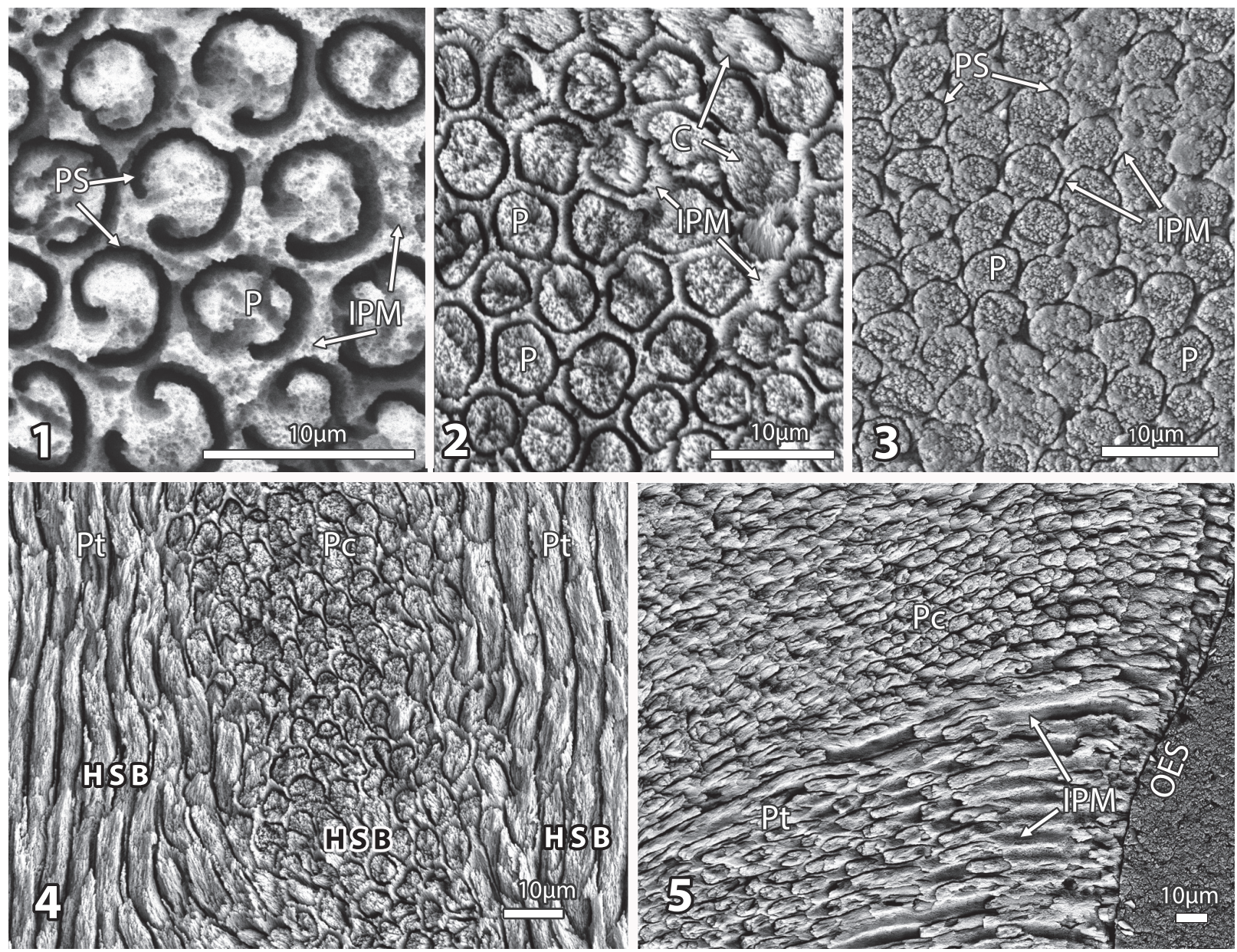

FIGURE 3. Crystallites and prisms in the enamel of Carodnia vieirai. SEM images. (3.1) Prisms in a tangential section (KOE 4122) with open prism sheaths. The crystallites are not visible. (3.2) Crystallites forming prisms and inter prismatic matrix in a tangential section (KOE 4212a). The rounded prisms have a closed prism sheath. (3.3) Transversal section of UFRJ-DG $315 \mathrm{M}$ showing prisms in cross-section with open prism sheaths etched away and appearing as a trench. (3.4) Prisms in HSB show different directions. One set occurs in cross-section the other more tangentially. Detail from the outer layer in a transverse section (KOE 4212e). (3.5) The enamel near the outer enamel surface in a transverse section (KOE 4121d). The prisms continue until the OES. IPM - interprismatic matrix, OES - outer enamel surface, $\mathrm{P}$ - prisms, PS - prism sheath.

in contrast to the term layers that have distinct borders in the schmelzmuster. For the investigation, a combination of SEM and RLM was important.

The innermost narrow zone of the enamel comprises radial enamel, where all prisms are parallel to each other and no decussating occurs. The thickness of this zone is irregular and comprises less than $10 \%$ of the enamel thickness.

The inner zone is a very complex in structure. It contains decussating prisms that are irregularly arranged in some kind of bands, but not as regular as in HSB (Figure 2.1-3). In a vertical section the inner zone looks like transversely oriented HSB (Figures 2.1 and 4.1). But this may be somewhat misleading because the structure occurs as very irregular in a transverse section. Even if the main orientation of these bands is transverse, the bands should be inclined from the EDJ towards the OES. But this is not visible in the vertical section (see Figure 2). The observed irregularities of the transverse section may be caused by bifurcations. The irregularities become even more obvious in the SEM mosaic (Figure 5). The structure of this zone cannot be fully deciphered because of the limited material that allows a precise orientation. The outer border of this zone is very irregular (Figure 2.1), and thus the thickness of this inner zone of decussating prisms varies between $30 \%$ and $50 \%$.

The outer zone is formed by vertical HSB that show an intensive bifurcation, as already observed 

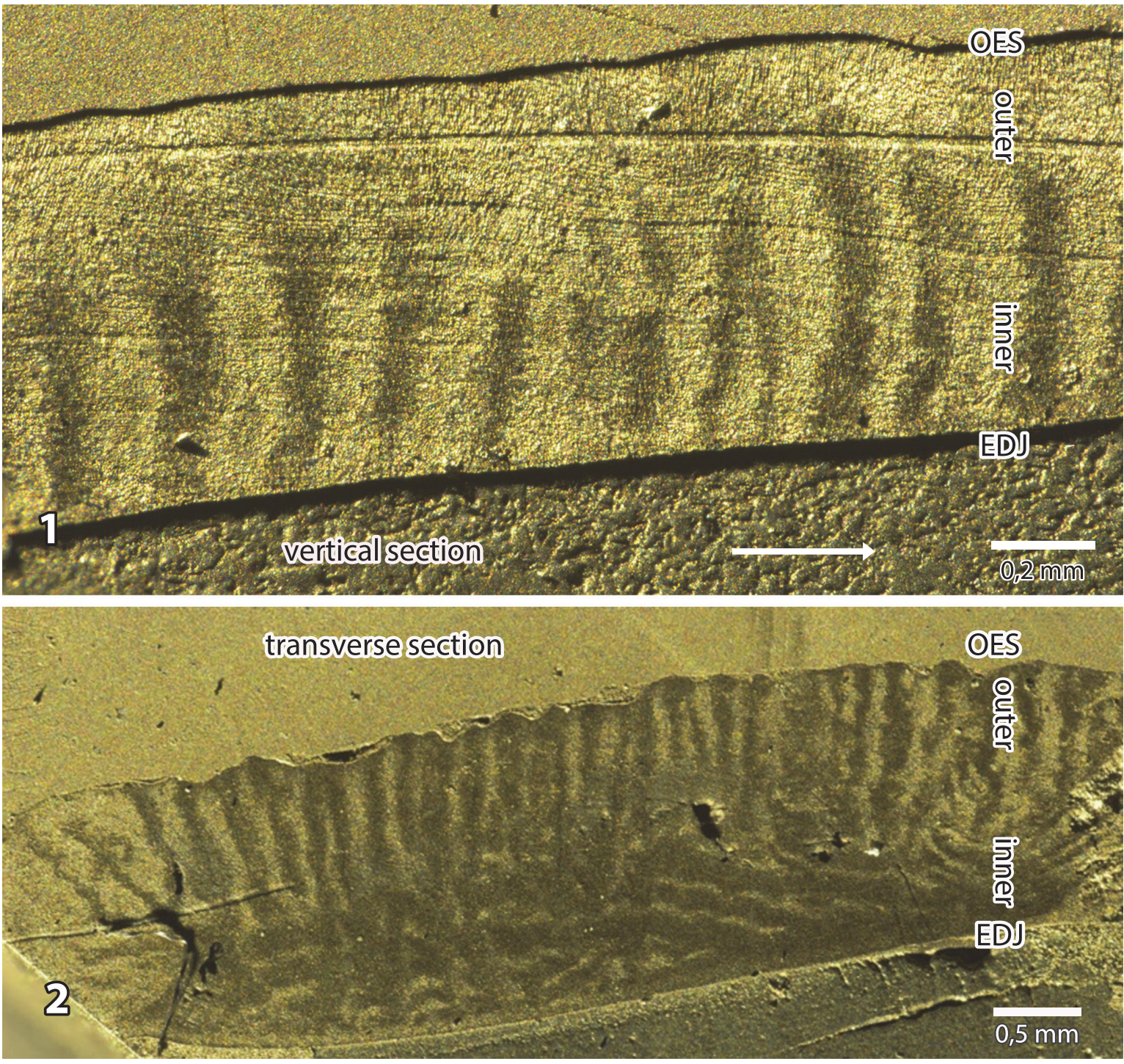

FIGURE 4. Vertical (4.1) and transverse (4.2) sections of the sputtered enamel of Carodnia vieirai in RLM. (4.1) KOE 4121, (4.2) KOE 4133. The arrow indicates the direction toward the occlusal surface.

by Line and Bergqvist (2005). Details are best seen in tangential sections (Figures 6.1-2). The general structure is recognizable only at a low magnification. Two sets of HSB with prisms oriented differently become visible in the RLM and the SEM as light and dark fields. They occur as long strips that bifurcate mainly in one direction. Thus, light and dark fields interdigitate. This unidirectional bifurcation is typical for HSB of most mammals (Koenigswald and Pfretzschner, 1987). At higher magnification, the tangential section shows narrow zones that appear darker between the light and dark sets of HSB, indicating areas of prisms with deviating orientation (Figure 6.3). These small areas are not randomly distributed, but always par- allel to the bands and of a much smaller scale. In these transitional zones the prisms change direction when passing from one band to the next.

Basically, the same pattern was verified in other sections by the RLM. A transverse and a vertical section of the specimen UFRJ-DG 315M showed two zones of HSB of different orientation (Figure 2.1-3). The thin innermost zone of radial enamel does not appear. The major inner zone has a variable appearance. It is interpreted as roughly horizontally oriented HSB with bifurcations. The outer zone shows the typical light and dark stripes originating from the different orientation of the prisms in the HSB. In this section, the outer zone is almost twice as thick as the inner one. In all sec- 


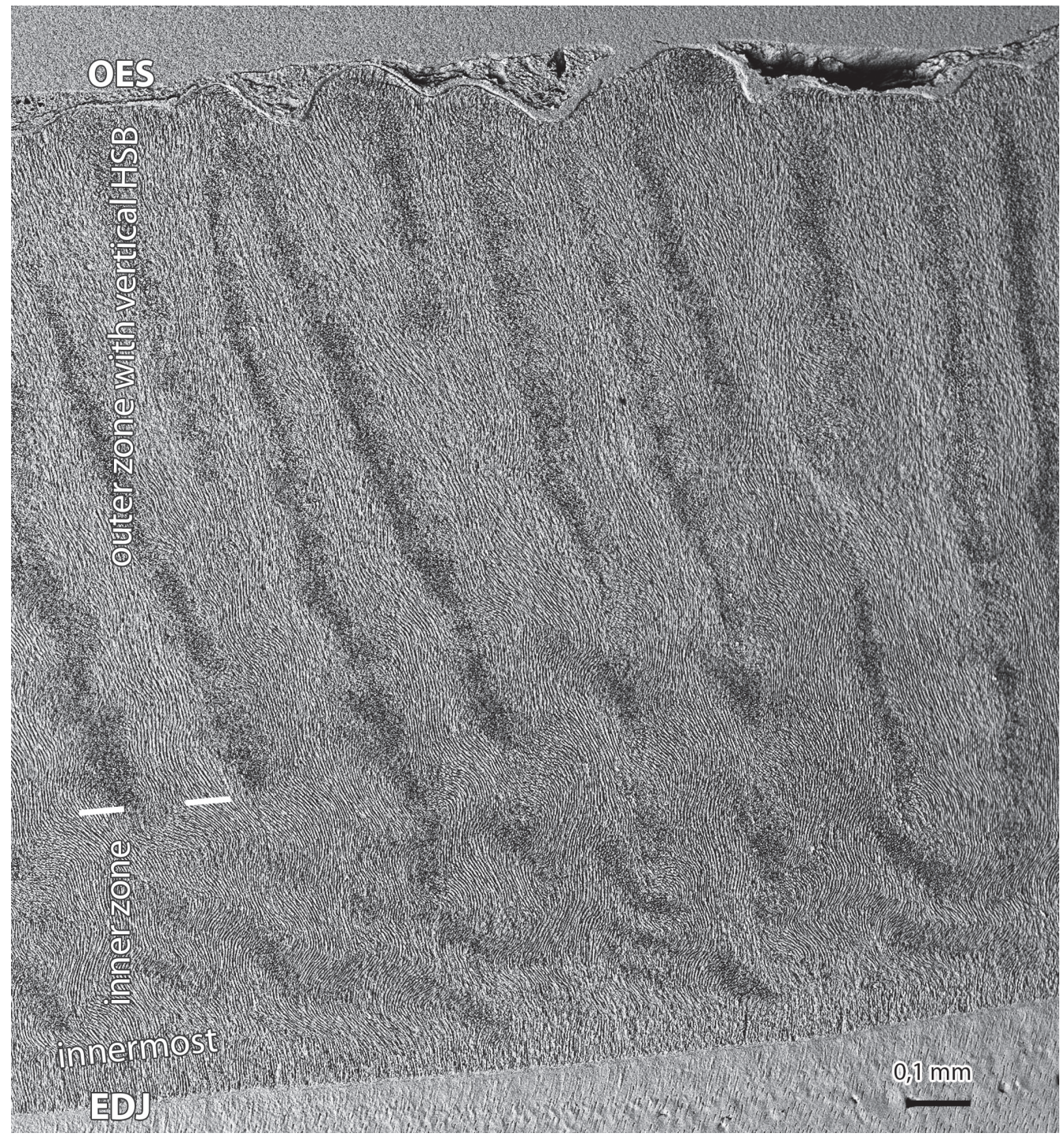

FIGURE 5. Transverse section of the enamel in Carodnia. Mosaic of two SEM images of KOE 4121, which shows the innermost zone of radial enamel, the inner zone of transverse HSB and the outer zone of vertical HSB. EDJ enamel-dentine junction, OES - outer enamel surface.

tions, the vertical HSB are restricted to the outer zone.

This general picture of the schmelzmuster of Carodnia vieirai contains two main zones with an irregular decussation in the inner one, and proper vertical HSB in the outer one. Line and Bergqvist (2005) had previously suggested the presence of a two layered-enamel in Carodnia after observing both vertical and transverse HSB in the cingulum of premolars and incisors, but it is also present in molars. Due to the limited material, we cannot decide whether there are differences between the leading and the trailing edges of the lophs. We could observe, however, that the inner zone is less distinct in areas where the enamel is strongly curved. From the external investigation, the bifurcations are more intense at the tip of the cusps, and the individual bands are thinner.

The SEM and RLM observations refer only to a molar and a premolar, thus we do not know whether this difference occurs at the dentition level in incisors or canines. Since these teeth have no highly-specialized morphology, we postulate a similar schmelzmuster for all Carodnia teeth as for the so far unknown deciduous dentition. 

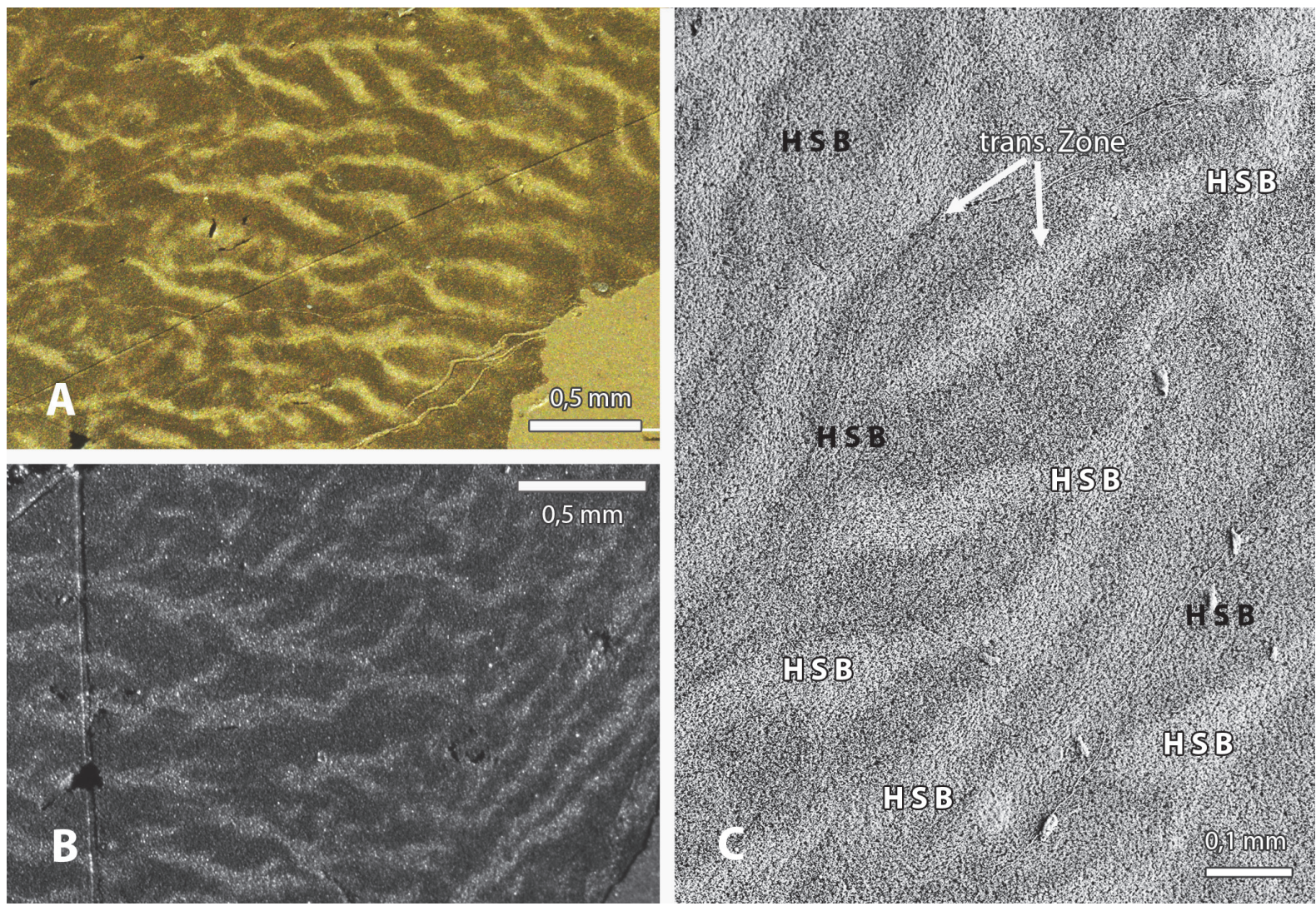

FIGURE 6. Vertical Hunter-Schreger bands in tangential sections of the enamel of Carodnia vieirai (KOE 4121). (6.1) and (6.2) show the orientation of the HSB illuminated in RLM. Note in (6.2) the changing direction towards the outer rim at the right. In higher magnification in the SEM image (6.3) the transitional zones appears somewhat darker.

\section{COMMENTS ON THE MASTICATION OF CARODNIA VIEIRAI}

The lower and upper molars of Carodnia vieirai are characterized by transverse lophs with very characteristic wear facets. Fortunately, two lower jaws provide different stages of wear. In the anterior loph of left $\mathrm{m} 3$ of DGM 334M (Figure 7.1) the unworn crest of the loph is visible. It is slightly overhanging in distal direction, where the facet will occur in a later wear stage. A slightly later wear stage is present on the $\mathrm{m} 2$ of the same jaw. The facets cut through the enamel and expose some dentine. It is a planar facet in bucco-lingual direction that is strongly inclined towards the distal side. This facet is only formed on the distal side of the lophs, whereas the mesial side does not show any facet. The second mandible belongs to the type specimen (DGM 333M) and is noticeably older. In the type specimen (Figure 7.2), the facet on the anterior lophs of the $\mathrm{m} 2$ and the $\mathrm{m} 3$ are worn distinctly more, but they still have the same orientation although less inclination. The dentine is partially exposed between the mesial and distal enamel bands, and excavated in relation to the level of the enamel ridges. This wear stage is the most important one. At a later wear stage the lophs collapse and form an almost horizontal grinding surface, as described for the tapiroid Lophiodon (Koenigswald, 2014). This is already the case of the first upper and lower molars of the holotype of Carodnia (DGM 333M). In the maxilla of DGM 335M the facets represent an earlier stage of wear. There, the inclined facets are found an all lophs of M1 and M2 and are located on the mesial sides.

The orientation of the facets, observed in Carodnia vieirai, is also present in the other species of the genus in the same way. On the photos of the mandible of the Peruvian Carodnia inexpectans (Antoine et al., 2015) and in the fragmented mandibles of $C$. cf. feruglioi (MPEF-PV 1874 and 1824) from Argentina (Gelfo et al., 2008), the planar facets are well recognizable on the distal side of the lophs. These examples confirm that these patterns of facets found in Carodnia vieirai are typical for the entire genus. 

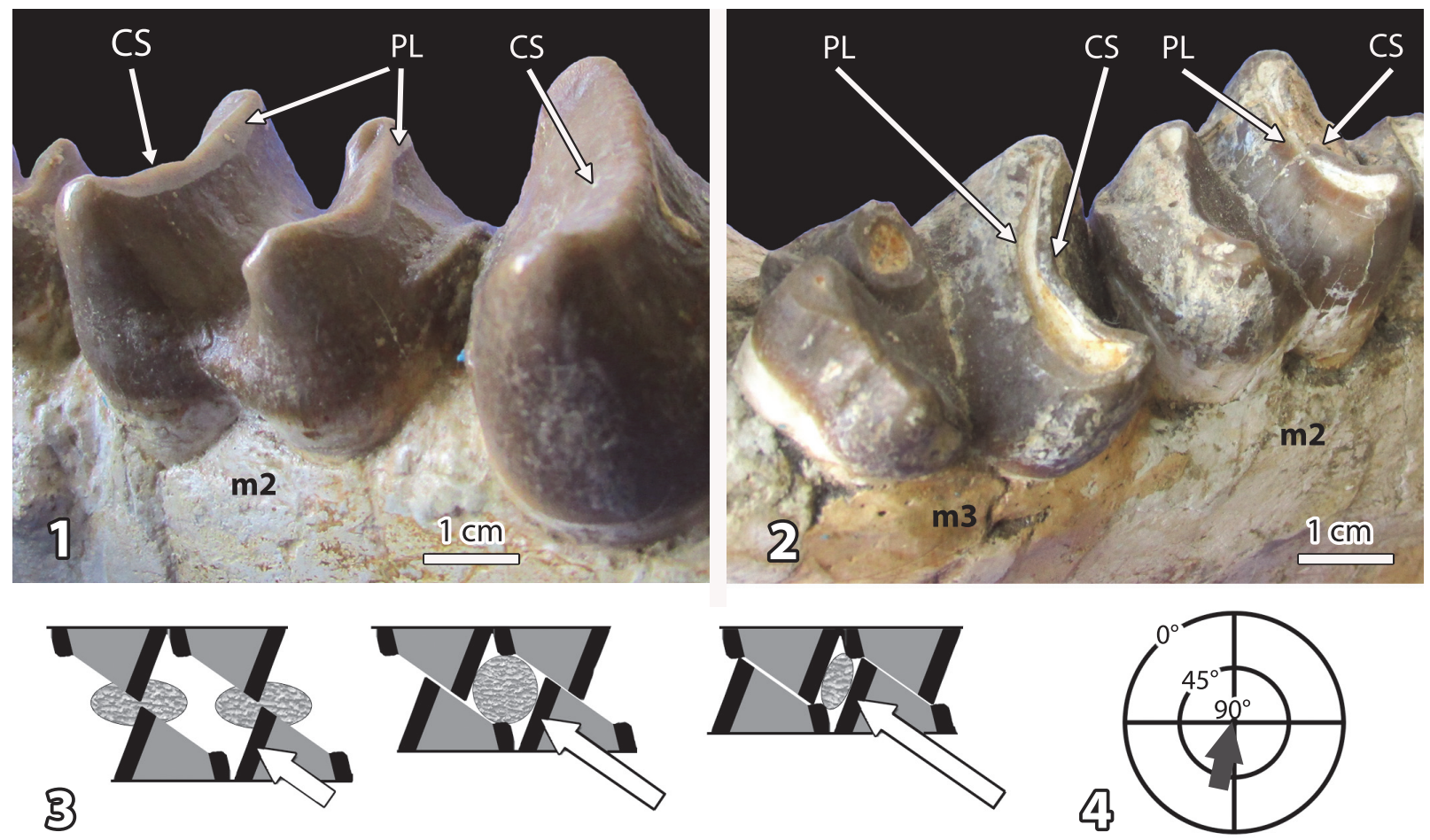

FIGURE 7. Tooth wear in the bilophodont molars of Carodnia vieirai. (7.1) Initial facets on the distal sides of the anterior loph of the left $\mathrm{m} 2$ (paratype, DGM 334M). (7.2) Planar wear facets on m2-m3 in a later stage of wear (holotype, DGM 333M). (7.3) Scheme for three stages of the interaction of lophs during phase I of the power stroke: cutting, compressing, central occlusion (modified from Koenigswald, 2014). (7.4) Mastication compass symbolizing the jaw moment in almost mesial direction with a high inclination.

These observations on the molars of Carodnia fit very nicely into the pattern of other dentitions with bilophodont molars. e.g., in the proboscidean Deinotherium, the pyrotherian Pyrotherium, or the tapiorid Lophiodon (Koenigswald, 2014; Koenigswald et al., 2015), and the pantothere Coryphodon. The same type of facets occurs even in macropodid marsupials.

The bilophodont molars of Carodnia vieirai can be assigned to the same wear pattern although the lophs differ somewhat in height. In Carodnia, the anterior lophs of the lower molars are more prominent than the distal one (Figures 1 and 7.12 ). In the uppers, the distal lophs are larger. These larger lophs show these one-sided planar facets in different stages of wear.

The function of these facets is very distinct. When the lower jaw occludes, it is moved in mesial direction, and the facets of upper and lower lophs occlude by sliding past each other. At the sharp end of both facets the food is cut like between the blades of scissors (Figure 7.3). While the blades continue to slide across the dentinal plane, the food is compressed between the leading enamel surfaces of the next lophs. These sides of upper and lower lophs are slightly concave. Both functions, cutting and subsequent compressing (grinding), belong to the phase I of the power stroke, because they occur prior to the central occlusion. The jaw movement is directed almost mesially and distinctly inclined (Figure 7.4), as symbolized for the left lower jaw in the mastication compass (Koenigswald et al., 2013). No facets indicate a phase II, as is common in most bilophodont dentitions (Koenigswald, 2014).

In contrast to grinding the food is not compressed between dentine fields before it is squeezed across the enamel crest, as in the teeth of cattle and horses. In many dentitions, there is a significant difference between the wear stages in the first and the last molar. Generally, the m1/M1 are more worn than the $\mathrm{m} 3 / \mathrm{M} 3$ because they erupt earlier and function for a longer time. This difference, however, may be as low or very distinct and described as "wear gradient" (Koenigswald, 2016). In Carodnia, the wear gradient is distinct, because the $\mathrm{M} 1 / \mathrm{m} 1$ has lost their inclined planar facets already at a time when the facets in $\mathrm{M} 3 / \mathrm{m} 3$ are just 
appearing. In comparison with high wear gradients in Lophiodon or Deinotherium, the wear gradient in Carodnia may be described as intermediate.

\section{DISCUSSION}

The relationship of Xenungulata is controversial and no consensus has been achieved. Schoch and Lucas (1985) proposed a close relationship between Carodnia (so far, the only known species of the order) and Dinocerata, nesting both in the non-ungulate mirorder Uintatheriamorpha. Bergqvist and Avilla (2003) consider the similarity in dental morphology between Xenungulata and Dinocerata a convergence between the two groups, as they present major differences in postcranial morphology. More recently, Xenungulata was linked to Tethytheria (O'Leary et al., 2013) and nested Carodnia within Pantodonta, as a sister taxon of Coryphodon (Muizon et al., 2015).

Therefore, it is of great interest, whether the enamel or the pattern of mastication found in Carodnia provides any information about the systematic relationships to other mammals? Convergent evolution, however, is very common in the enamel and thus similarities should be used only very carefully for phylogenetic reconstructions.

\section{The Enamel}

The variability of prisms in cross section, as observed in Carodnia, is not unusual. Prisms with an open or closed prisms sheath are regarded to be the underived situation. The prisms with an incomplete prism sheath are not as regular and densely packed as in the keyhole prisms found in Colombitherium and Pyrotherium (Koenigswald et al., 2015). The IPM parallel to the prisms is underived as well. There is a general tendency in the differentiation of the enamel to increase the angle between prisms and IPM. Similarly, to the decussation prisms, it strengthened the enamel against crack propagation. There is no close relationship between crown morphology and IPM orientation. IPM oriented at an angle towards the prisms, often perpendicular, is a more derived stage. In several herbivores, the IPM forms sheets between rows of prisms (Pfretzschner, 1994). None of such differentiations were seen in Carodnia. The few prisms that resemble the keyhole pattern found in various proboscideans, do not confirm any relationship to Tethytheria.

Early Paleocene marks the first appearance of HSB (Koenigswald et al., 1987). The occurrence of HSB, predominantly in animals of larger body size (except large marsupials), has traditionally been interpreted as a biomechanical protection against the increased tension forces generated in mastication (Koenigswald et al., 1987; Pfretzschner, 1994). A vertical configuration of HSB was a relatively common feature in large lophodont herbivores during the Paleogene and Neogene (Rensberger and Koenigswald, 1980; Fortelius, 1984, 1985; Line and Bergqvist, 2005).

The most obvious structure in the enamel of Carodnia is the vertical HSB. We think that we can differentiate these structures a bit more by regarding the transitional zones between those bands. On the one hand, there are "typical vertical HSB" as in the rhino Coelodonta (Rensberger and Koenigswald, 1980), characterized by a narrow transitional zone without additional structures. The vertical HSB in Carodnia belong to this type. On the other hand, there are vertical HSB-like structures with broad transitional zones that have very complex internal structures. The enamel of Pyrotherium or Coryphodon shows such complex structures with vertical elements, therefore they were separated as different enamel types (Koenigswald and Rose, 2005, Koenigswald et al., 2015). Even the zigzag-enamel of Carnivora (Stefen, 1997) may be discussed as a modification within this second group.

Typical vertical HSB evolved independently in various mammalian lineages. This is even more the case for the enamel types with complex transitional zones.

Besides the enamel type, its position in the schmelzmuster is of significance. The typical vertical HSB in most rhinos, e.g., in Coelodonta, form the inner layer and are combined with radial enamel in the outer layer. In Astrapotherium and some other Astrapotheiidae and Trigonostylopidae, a similar schmelzmuster with vertical HSB in an inner layer was observed (Lindenau, 2005; Koenigswald et al., 2015). In Carodnia, however, the vertical HSB are placed in an outer zone combined with transverse HSB in an inner zone. Such a schmelzmuster is rare. The only comparable schmelzmuster, the compound HSB, was found in Hyrachyus, Deperetellidae and Uintaceras (Koenigswald et al., 2011). Within the perissodactlys this schmelzmuster evolved independently, and thus the similarity with the schmelzmuster of Carodnia does not represent a specific relationship.

The selective advantage of decussating prisms in HSB is reducing the danger of crack propagation (e.g., Pfretzschner, 1994). The special advantage of vertical HSB in rhinos was inter- 
preted as a possibility of reducing tooth wear (Rensberger and Koenigswald, 1980), because truncated prisms might be more resistant than prisms that are met tangentially by the wear facet. However, experimental data are still missing.

\section{Pattern of Mastication}

The facets observed on the bilophodont molars of Carodnia were compared with the bilophodont molars of Pyrotherium and others. In the Paleogene, such bilophodont molars occurred quite frequently, called brachydont-transverselophodont teeth (BTL) by Hooker (2000). He figured the uintatherian Prodinotherium, the pantodont Coryphodon, and the embrithopodan Phenacolophus. From the ancient faunas of South America, the xenungulate genus Carodnia and the pyrothere Pyrotherium need to be discussed here. Even if in Carodnia the bilophodonty is not as well developed as in Pyrotherium, both genera represent the same pattern of mastication as common in the BTL-teeth. They all have the scissor-like symmetrical blade-facets that slide past each other and subsequently compress the food between the leading enamel sides of the next lophs. From the more modern fauna, tapirs and the proboscidean deinotheres represent this pattern of mastication. The diverse occurrence of this pattern stresses that its occurrence does not reflect phylogenetic relationships.

Some (superficial) similarities with Coryphodon, Pyrotherium, and Astrapotherium from South America were found. They all share some kind of vertical HSB, but as discussed, they differ in significant details of the schmelzmuster. Coryphodon and Carodnia share the pattern of mastication, but this specific type evolved in several mammalian groups convergently. Thus, the investigation of the enamel and the mastication pattern of Carodnia did not provide new conclusive clues to the systematic position of Carodnia and the Xenungulata, but it provided new aspects in the diversity and function of mammalian teeth.

However, the horizontal wear facets oriented distally in lower molars, observed in different species of Carodnia, is also present in other taxa of the order, as Etayoa (Villarroel, 1987) and Notoetayoa (Gelfo et al., 2008). Both bear more primitive dentition, bearing only a little-developed protolophid and no hypolophid. This is suggestive that the pattern of mastication is not strictly related to tooth morphology but may be a phylogenetic signal of the order.

\section{ACKNOWLEDGEMENTS}

The authors would like to thank T. Martin of the Steinmann Institute at the University of Bonn, J.G. Mendonça Filho of Laboratório de Palinofacies e Facies Orgânicas at Universidade Federal do Rio de Janeiro (UFRJ), and L.C. Bertolino of Setor de Caracterização Tecnológica at Centro de Tecnologia Mineral, Rio de Janeiro (CETEM) for the facilities provided for SEM use. Thanks are extended to L. Andrade of Laboratório de Biomineralização at UFRJ for the facilities to prepare and photograph the specimen UFRJ-DG 315M. For technical assistance we thank G. Oleschinski and P.Göddertz, both in Bonn. We also thank C. Lochs for reviewing an early and the latest versions of the manuscript and the two anonymous reviewers, whose comments and suggestions improved the final version of the manuscript. This research was supported by Conselho Nacional de Pesquisa (CNPq) to LPB and by the "Deutsche Forschungsgemeinschaft" (DFG, German Research Foundation) and is publication no. 87 of the DFG research Unit 771 "Function and performance enhancement in the mammalian dentition - phylogenetic and ontogenetic impact on the masticatory apparatus" to WvK.

\section{REFERENCES}

Abranches, C.T.S. 2012. Carodnia vierai (Mammalia: Xenungulata): uma linhagem evolutiva única? Inferências através de microdesgaste dentário e morfometria geométrica da mandíbula. Unpublished PhD Thesis, Universidade Federal do Rio de Janeiro, Rio de Janeiro, Rio de Janeiro, Brazil.

Antoine, P.-O., Billet, G., Salas-Gismondi, R., Lara, T.J., Baby, P., Brusset, S., and Espurt, N. 2015. A New Carodnia Simpson, 1935 (Mammalia, Xenungulata) from the Early Eocene of Northwestern Peru and a Phylogeny of xenungulates at Species Level. Journal of Mammalian Evolution, 22:129-140.

Avilla, L.S. and Bergqvist, L.P. 2003. Sobre o hábito locomotor de Carodnia vieirai Paula-Couto, 1952 (Mammalia: Xenungulata). Livro de Resumos do II Congresso Brasileiro de Mastozoologia, Belo Horizonte, Brasil, p. 278.

Avilla, L.S. and Bergqvist, L.P. 2005. Estimativa de massa e padrões de locomotores do mais antigo mamífero de grande porte da América do Sul. Livro de Resumos do III Congresso Brasileiro de Mastozoologia, Aracruz, Brasil, p. 142.

Bergqvist, L.P., Abranches, C., Morato, L., and Avilla, L. 2008b. A tale of two mandibles: problems concerning specimens assigned to Carodnia vieirai. Journal of Vertebrate Paleontology, 28(3):51A.

Bergqvist, L.P. and Avilla, L.S. 2003. New approaches to Carodnia vieirai (Mammalia, Xenungulata) of the São 
José de Itaboraí basin (Itaboraian). Boletim de Resumos do XVIII Congresso Brasileiro de Paleontologia, Brasília, Brasil, p. 66

Bergqvist, L.P., Avilla, L.S., and Porpino, K.O. 2006. Adição ao conhecimento da morfologia crânioesquelética de Carodnia vieirai Paula-Couto (Mammalia: Xenungulata). Ameghiniana, 43:25R.

Bergqvist, L.P., Avilla, L.S., Porpino, K.O., and Abranches, C.T.S. 2008a. O enigma de Carodnia vieirai (Mammalia, Xenungulata), da Bacia de S.J. de Itaboraí/RJ (Paleoceno superior). Boletim de Resumos do VI Simpósio Brasileiro de Paleontologia de Vertebrados, Paleontologia em Destaque, (Edição Especial Agosto):41-42.

Bergqvist, L.P. and Metello, T.M. 2011. Body mass estimates of fossil ungulates of Itaboraí basin, Brazil. Ameghiniana, 48:R142-R143.

Bergqvist, L.P. and Powell, J.E. 2004. A new xenungulate from the Rio Loro Formation (Paleocene) from Tucumán province (Argentina). Ameghiniana, 41(4):36R.

Bond, M., Carlini, A.A., Goin, F.J., Legarreta, L., OrtizJaureguizar, E., Pascual, R., and Uliana, M.A. 1995. Episodes in South American land mammal evolution and sedimentation: testing their apparent concurrence in a Paleocene succession from central Patagonia. Actas VI Congreso Argentino de Paleontología y Bioestratigrafía, Trelew, Argentina, p. 47-58.

Boyde, A. 1965. The structure of developing mammalian dental enamel, p. 163-194. In Stark, M. and Fearnhead, R. (eds.), Tooth Enamel. John Wright \& Sons, Bristol.

Dalcusi, G.J., Mentaneau, J., Kerebel, L.M., and Mitre, D. 1984. Length and shape of enamel crystals. Calcified Tissue International, 36:550-555.

Fortelius, M. 1984. Vertical decussation of enamel prisms in lophodont ungulates p. 427-431. In Fearnhead, R. and Suga, S. (eds.), Tooth Enamel IV. Elsevier, Amsterdam.

Fortelius, M. 1985. Ungulate cheek teeth: Developmental, functional and evolutionary interrelations. Acta Zoologica Fennica, 180:1-76.

Gelfo, J.N., Goin, F.J., Woodburne, M.A., and Muizon, C. de. 2009. Biochronological relationships of the earliest South American Paleogene mammalian faunas. Palaeontology, 52:251-269.

Gelfo, J.N., López, G.M., and Bond, M. 2008. A new Xenungulata (Mammalia) from the Paleocene of Patagonia, Argentina. Journal of Paleontology, 82:329-335.

Hooker, J.J. 2000. Ecological response of mammals to global warming in the late Paleocene and early Eocene. Geologiska Föreningens Förhandlingen GFF, 122:77-79.

Kalthoff, D. 2000. Die schmelzmikrostruktur in den Incisven der hamsterartigen nagetiere und anderer Myomorpha (Rodentia, Mammalia). Palaeontographica Abteilung, A259:1-193.
Koenigswald, W.v. 1980. Schmelzstruktur und morphologie in den molaren der Arvicolidae (Rodentia). Abhandlungen der Senckenbergischen Naturforschenden Gesellschaft, 539:1-129.

Koenigswald, W.v. 1997a. Brief survey of the enamel diversity at the schmelzmuster level in Cenozoic placental mammals, p. 137-161. In Koenigswald, W.v. and Sander, P.M. (eds.), Tooth Enamel Microstructure. Balkema, Rotterdam.

Koenigswald, W.v. 1997b. Evolutionary trends in the differentiation of mammalian enamel ultrastructure, $p$. 203-235. In Koenigswald, W.v. and Sander, P.M. (eds.), Tooth Enamel Microstructure. Balkema, Rotterdam.

Koenigswald, W.v. 2014. Mastication and wear Lophiodon (Perissodactyla, Mammalia) compared to lophodont dentitions in some other mammals. Annales Zoologici Fennici, 51:162-176.

Koenigswald, W.v. 2016. Specialized wear facets and late ontogeny in mammalian dentitions. Historical Biology, DOI: 10.1080/08912963.2016.1256399.

Koenigswald, W.v., Anders, U., Engels, S., Schultz, J.A., and Kullmer, O. 2013. Jaw movement in fossil mammals: analysis, description and visualization. Paläontologische Zeitschrift, 87:141-159.

Koenigswald, W.v. and Clemens, W.A. 1992. Levels of complexity of the microstructure of mammalian enamel and their application in studies of systematics. Scanning Microscopy, 6:195-218.

Koenigswald, W.v., Holbrook, L.T., and Rose, K.D. 2011. Diversity and evolution of Hunter-Schreger Band configuration in tooth enamel of perissodactyl mammals. Acta Palaeontologica Polonica, 56:11-32.

Koenigswald, W.v., Martin, T., and Billet, G. 2015. Enamel microstructure and mastication in Pyrotherium romeroi (Pyrotheria Mammalia). Paläontologische Zeitschrift, 89:593-609.

Koenigswald, W.v. and Pascual, R. 1990. The Schmelzmuster of the Paleogene South American rodentlike marsupials Groeberia and Patagonia compared to rodents and other Marsupialia. Palaeontologische Zeitschrift, 64:345-358.

Koenigswald, W.v. and Pfretzschner, H.U. 1987. Hunter-Schreger-Bänder im Zahnschmelz von Säugetieren (Mammalia): Anordnung und Prismenverlauf. Zoomorphology, 106:329-338.

Koenigswald, W.v., Rensberger, J.M., and Pretzschner, H.U. 1987. Changes in the tooth enamel of early Paleocene mammals allowing increased diet diversity. Nature, 328:150-151.

Koenigswald, W.v. and Rose, K.D. 2005. The enamel microstructure of the Early Eocene pantodont Coryphodon and the nature of the zigzag enamel. Journal of Mammalian Evolution, 12:419-432.

Koenigswald, W.v. and Sander, P.M. 1997. Glossary of terms used for enamel microstructures, p. 267-280. In Koenigswald, W.v. and Sander, P.M. (eds.), Tooth Enamel Microstructure. Balkema, Rotterdam. 
Line, S.R.P. and Bergqvist, L.P. 2005. Enamel structure of Paleocene mammals of the São José de Itaboraí Basin, Brazil. 'Condylarthra', Litopterna, Notoungulata, Xenungulata and Astrapotheria. Journal of Vertebrate Paleontology, 25:924-928.

Lindenau, C. 2005. Zahnschmelzmikrostrukturen südamerikanischer huftiere. Unpublished PhD Thesis, Rheinische Friedrich-Wilhelms, Bonn, Germany.

Loch, C., Kieser, J.A., and Fordyce, R.E. 2015. Enamel ultrastructure in fossil cetaceans. Plos One, 10:e0116557

Marshall, L.G. 1985. Geochronology and land-mammal biochronology of the transamerican faunal interchange, p. 49-85. In Stehli, F.G. and Webb, S.D. (eds.), The Great American Biotic Interchange, Plenum, New York.

Metello, T.M. and Bergqvist, L.P. 2012. Estimativa de massa corpórea de ungulados (Mammalia) da Bacia de Itaboraí (Itaboraiense) a partir de equações alométricas baseadas em dentes. Boletim de Resumos do VIII Simpósio Brasileiro de Paleontologia de Vertebrados, Paleontologia em Destaque (Edição Especial Agosto):139.

Muizon, C. de, Billet, G., Argot, C., Ladevèze, S., and Goussard, F. 2015. Alcidedorbignya inopinata, a basal pantodont (Placentalia, Mammalia) from the early Palaeocene of Bolivia: anatomy, phylogeny and palaeobiology. Geodiversitas, 37:397-634.

O'Leary, M.A., Bloch, J.I., Flynn, J.J., Gaudin, T.J., Giallombardo, A., Giannini N.P., Goldberg, S.L., Kraatz, B.P., Zhe-Xi, L., Meng, J., Xijun, N., Novacek, M.J., Perini, F.A., Randall, Z.S., Rougier, G.W., Sargis, E.J., Silcox, M.T., Simmons, N.B, Spaulding M., Velazco, P.M., Weksler, M., Wible, J.R., and Cirranello, A.L. 2013. The placental mammal ancestor and the post-K-Pg radiation of placentals. Science, 339:662-667.

Paula-Couto, C. 1952. Fossil mammals from the beginning of the Cenozoic in Brazil. Condylarthra, Litopterna, Xenungulata and Astrapotheria. Bulletin of the American Museum of Natural History, 99:359394.
Pfretzschner, H.U. 1994. Biomechanik der schmelzmikrostruktur in den backenzähnen von Großsäugern. Palaeontographica, A234:1-88.

Rensberger, J.M. 2000. Pathways to functional differentiation in mammalian enamel, p. 252-268. In Teaford, M.F., Smith, M.M., and Ferguson, M.W.J. (eds.), Development, Function and Evolution of Teeth. Cambridge University Press, Cambridge.

Rensberger, J.M. and Koenigswald, W.v. 1980. Functional and phylogenetic interpretation of enamel microstructure in rhinoceroses. Paleobiology, 6:477495.

Schoch, R.M. and Lucas, S.G. 1985. The phylogeny and classification of the Dinocerata (Mammalia, Eutheria). Bulletin of the Geological Institute of the University of Uppsalla, New Series, 11:1-48.

Simpson, G.G. 1935. Descriptions of the oldest known South American mammals from the Rio Chico formation. American Museum Novitates, 793:1-25.

Stefen, C. 1997. The enamel of Creodonta, Arctocyonidae, and Mesonychidae (Mammalia), with special reference to the appearance of Hunter-Schreger Bands. Paläontologische Zeitschrift, 71:291-303.

Villarroel, C.A. 1987. Características y afinidades de Etayoa n. gen., tipo de una nueva familia de Xenungulata (Mammalia) del Paleoceno medio (?) de Colombia. Comunicaciones Paleontológicas del Museo de Historia Natural de Montevideo, 19:241253.

Woodburne, M.A., Goin, F.J., Bond, M., Carlini, A., Gelfo, J.N., López, G.M., Iglesias A., and Zimicz, A.N. 2014b. Paleogene Land Mammal Faunas of South America; a Response to Global Climatic Changes and Indigenous Floral Diversity. Journal of Mammalian Evolution, 21:1-73.

Woodburne, M.A., Goin, F.J., Raigemborn, M.S., Heizler, M., Gelfo, J.N., and Oliveira, E.V. 2014a. Revised timing of the South American early Paleogene land mammal ages. Journal of South American Earth Sciences, 54:109-119. 